\title{
Structural Collaboration Process, Staff and Noncivil Servant in Job Seeker Card Service (AK-1)
}

\author{
Muhamad Taufik*1), Iqbal Miftakhul Mujtahid2) \& Rino Ardhian Nugroho3) \\ 1)Master of Public Administration, Postgraduate, Universitas Terbuka, Indonesia \\ 2) Public Administration Program, Universitas Terbuka, Indonesia \\ 3)Faculty of Social and Political Sciences, Universitas Sebelas Maret, Indonesia
}

Received: 22 June 2021; Reviewed: 22 June 2021; Accepted: 31 July 2021

* Corresponding Email: muhamad.taufik.bachrunsyah@gmail.com

\begin{abstract}
This study aims to investigate the strategy taken by the Department of Manpower and Industry of the city of Tarakan in overcoming the job seeker card service (AK-1). Focused the problem was on collaboration between structural officials, staff, and noncivil servants. To solve this problem, using the theoretical references of Chris Ansell and Alisson Gash were used. The data were collected through interviews, observation, and documentation and analyzed qualitatively. This study concludes that the collaboration process between structural officials, staff, and noncivil servants at the Department of Manpower and Industry of Tarakan was going well. The strategy for making job seeker cards was able to be applied. The service supporting factor was the existence of Information Technology (IT)-based applications, an inhibiting factor from services due to the Covid-19 pandemic. Services are still carried out based on health procedures set by the government.
\end{abstract}

Keywords: Strategy; Collaboration; Job Seeker Card Services; The Covid-19 Pandemic.

How to Cite: Taufik, M., Mujtahid, I.M., \& Nugroho, R.A., (2021). Structural Collaboration Process in the Job Seeker Card Service (AK-1). ). Jurnal Administrasi Publik (Public Administration Journal). 11 (2): 121-129 
Muhamad Taufik, Iqbal Miftakhul Mujtahid \& Rino Ardhian Nugroho, Structural Collaboration Process, Staff and Non ASN in Job Seeker Card Service (AK-1)

\section{INTRODUCTION}

The Department of Manpower and Industry of Tarakan City, an agency that provides services, is required to maximize the level of service to facilitate that job seeker. From the problems found during the pre-survey at the Department of Manpower and Industry of Tarakan City, namely inadequate service facilities and infrastructure, limited human resources (operators), and lack of functional technical employees (JFT) when compared to the number of job seekers registered each year, it shows there are indications of an imbalance that results in the quality of services, especially for job seekers. The basis for conducting this study are: (a). To test and prove the concept and theory of collaboration on the problem of service users of job seeker cards (AK-1) at the Manpower and Industry Office of Tarakan City, (b). To gain knowledge and contribute or create added value to research related to collaboration.

Collaboration is a collaboration and interaction and a compromise of several related elements both from individuals, parties, and institutions involved indirectly and directly who get the consequences and benefits of Haryono (Irawan, 2017). Wood and Gray in Fairuza (2017) said collaboration is a mutually beneficial relationship between two parties to cooperate and share authority, responsibility, and accountability to achieve common goals.

Ansell, C., \& Gash (2007)say that collaborative processes have variables. The collaborative process variable is the core of the model proposed by Ansell-Gash, with the initial conditions, institutional design, and leadership variables being represented as significant contributions or contexts for the collaborative process.

This study used the theory of Ansell and Gash (2007) in analyzing the collaboration process. Among these variables are: Face-to-face dialogue is a form of communication that is important in the collaboration process because of forming consensus. Trust-building is a necessary condition for building a solid collaboration process. Collaboration requires intensive communication. Commitment to the collaboration process (commitment to the process) is an essential component in the collaboration process. Shared understanding is essential in achieving a common goal. Intermediate outcomes of this condition occur during the collaboration process; therefore, the word "temporary" in its meaning has a positive value, which is referred to as small wins.

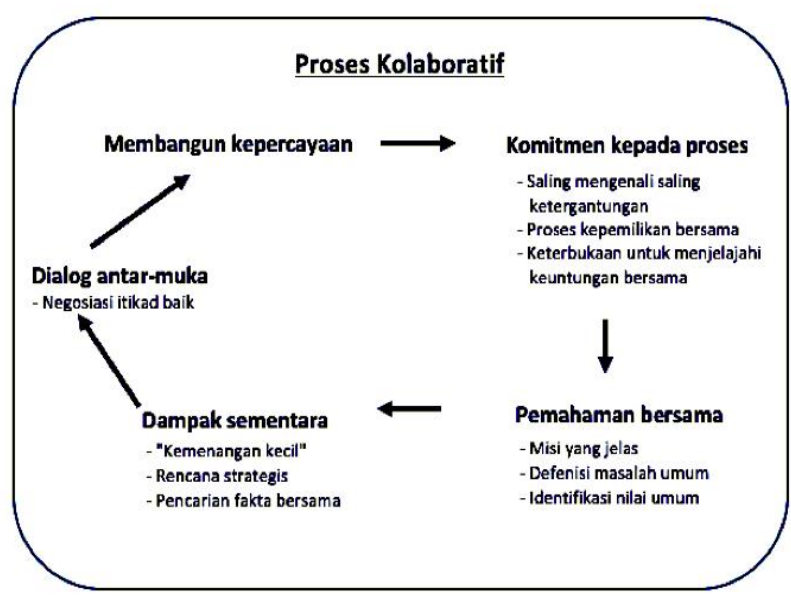

Figure 1. Collaboration process Source: Ansell and Gash, 2007.

The collaboration process between the bureaucratic apparatus, in this case, involves structural and non-structural officials at the Department of Manpower and Industry of Tarakan City, especially in making policies to overcome problems that occur in public services. Moenir (2014)defines service as an activity carried out by individuals or groups of people with interests. Groonros in Ratminto \& Septiwinarsi (2005) that service is an activity or a series of intangible activities and occur as a result of interaction between employees and leaders.

Agustina (2017) discussed the collaboration between the government and non-governmental institutions/agencies collaboratively carried out by various multi-acters. Each of these actors has been 
divided into roles according to their expertise. Liu, X., \& Zheng (2018) discussed the effectiveness of cross-departmental collaboration influenced by administrative reforms and personal relations between officials and staff. Whereas Ramadass, SD, Sambasivan \& Xavier (2018) said that collaboration between public bodies is essential to deal with social problems effectively.

This study was conducted to test and prove the concept of collaboration theory on the problem of job seeker card service (AK-1) at the Department of Manpower and Industry of Tarakan City and gain knowledge and contribute or create added value to study related to collaboration.

\section{RESEARCH METHOD}

This study conducted qualitative techniques to examine the extent of collaboration between the bureaucratic apparatus and the service of making cards for job seekers.

The focus of this study used qualitative methods related to the formulation of the problem. The focus of the study was able to develop and change based on the development of discoveries and problems.

The participants in this study were the Head of Service, Secretary of the Service, Head of Manpower, Lattas Penta Section Staff, Operator Officers, and job seekers who came to the Manpower Industry Office of Tarakan City. More details were able to be seen in table 1 .

Table 1.

Research participants

\begin{tabular}{llcc}
\hline No & Research subject & Participants & Participant Key \\
\hline $\mathbf{1}$ & $\begin{array}{l}\text { Head of the Department of Manpower and Industry of } \\
\text { Tarakan City }\end{array}$ & - & 1 \\
\hline $\mathbf{2}$ & $\begin{array}{l}\text { Secretary of the Department of Manpower and } \\
\text { Industry of Tarakan City }\end{array}$ & - & 1 \\
\hline 3 & Head of Employment & - & 1 \\
\hline 4 & Satff Sexy Lattas Penta & $\mathbf{2}$ & - \\
\hline 5 & Service Operators & $\mathbf{2}$ & - \\
\hline 6 & Job Seeker Society & 10 & - \\
\hline \multicolumn{1}{c}{ Amount } & $\mathbf{1 4}$ & 3 \\
\hline
\end{tabular}

Source: Researcher modification.

The instrument of this study was the researcher himself with media facilities that were used as supporting tools such as voice recorders, digital cameras, field notes. In addition, a general guide to interviews and to complete the data obtained using a questionnaire to collect necessary data and information.

In-depth interviews were. They used them to explore participants' experiences in-depth to find the phenomena to be studied. In-depth interviews were conducted using a semi-structured interview guide.

Observations of the data collection were done by looking directly at the actual conditions of the social field to understand the events faced by the subject. Made Observations by systematically recording the symptoms that were the focus of the study.

Used documentation of this study as supporting secondary data to capture a real moment or condition at the Department of Manpower and Industry of Tarakan City. Other evidence in the form of work documents as part of data collection.

The unit of analysis of this study was the Department of Manpower and Industry of Tarakan City. The method used is analysisMiles, MB, Huberman, AM, \& Saldana (2015) to find out the collaboration process at the Department of Manpower and Industry of Tarakan City in formulating 
a service strategy to find out what factors influence the job seeker card service.

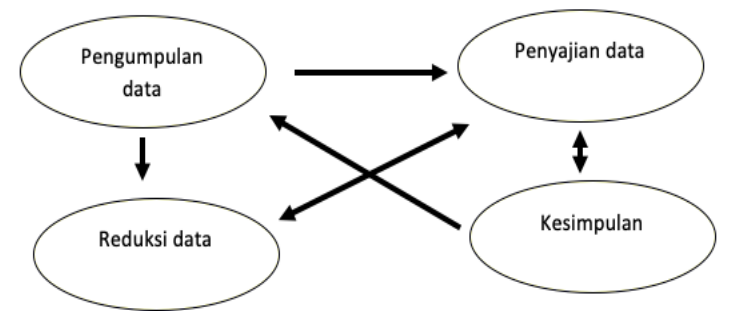

Figure 2. Analysis of qualitative data Source: Miles, Huberman and Saldana, 2015

\section{RESULTS AND DISCUSSION}

This study related to the collaboration of bureaucratic apparatus in formulating public services is as follows: Ramadass, SD, Sambasivan \& Xavier (2018) said that collaboration between public bodies was essential to deal with social problems effectively. The study conducted as Agustina (2017) discusses that the collaboration between the government and non-governmental institutions/agencies is carried out by various multi-actor collaboratively, where each of these actors has been divided into roles according to their expertise. Participants P8 to P17 thought that the services provided by the officers were by the procedures; job seekers have also explained the procedure for filling out the registration form. The officers were also always on standby at the service counter so that people who wanted to make job seeker cards were no longer looking for officers because they were not there.

\section{Face-to-face dialogue.}

The face-to-face dialogue at the Department of Manpower and Industry of Tarakan City had gone well. These activities were carried out related to the implementation of policies, socialization of new regulations, and finding solutions to problems in the service. Face to face was part of direct communication that was carried out to convey ideas or ideas in response to problems or find solutions.

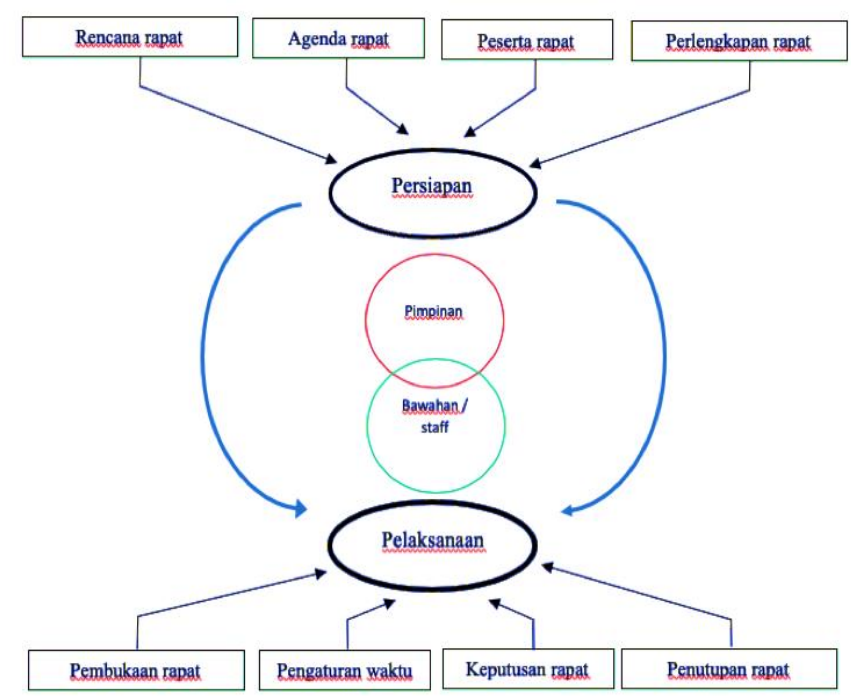

Figure 3. Diagram of the face-to-face process Source: Plummer, 2004

The process of face-to-face communication in this study between leaders and subordinates did not occur incidentally but through a series of processes starting from preparation to the implementation of the face-to-face meeting itself. This phenomenon was in line with what Plummer (2004) stated, who said that "face-to-face dialogue is at the heart of the process of building trust, mutual respect, mutual understanding and commitment to the process." Sometimes, the face-to-face dialogue was formally and informally in the form of direct instructions to subordinates related to the implementation of official duties. Jensen, UT, Moynihan, DP, \& Salomonsen (2018) stated that face-to-face dialogue is the most effective medium for communicating a vision since it is a rich form of communication that combines the ability to provide multiple information cues, offer feedback to foster shared understanding and meaning, and personalize messages to recipients such as employees. The P3 submission explains that:

"We hold meetings that are urgent in nature, it is at those meetings that we communicate to our leaders and subordinates regarding service tasks including service on job seeker cards. Formally through meetings but sometimes 
there are also informal ones using technology (whatsapp)".

\section{Building Trust (Trust Building)}

Building trust was the result (output) of good communication which means there is an open relationship between one individual and another. One of the foundations for building trust was completing the work by the task orders given, in this case, the leader or mutual agreement.

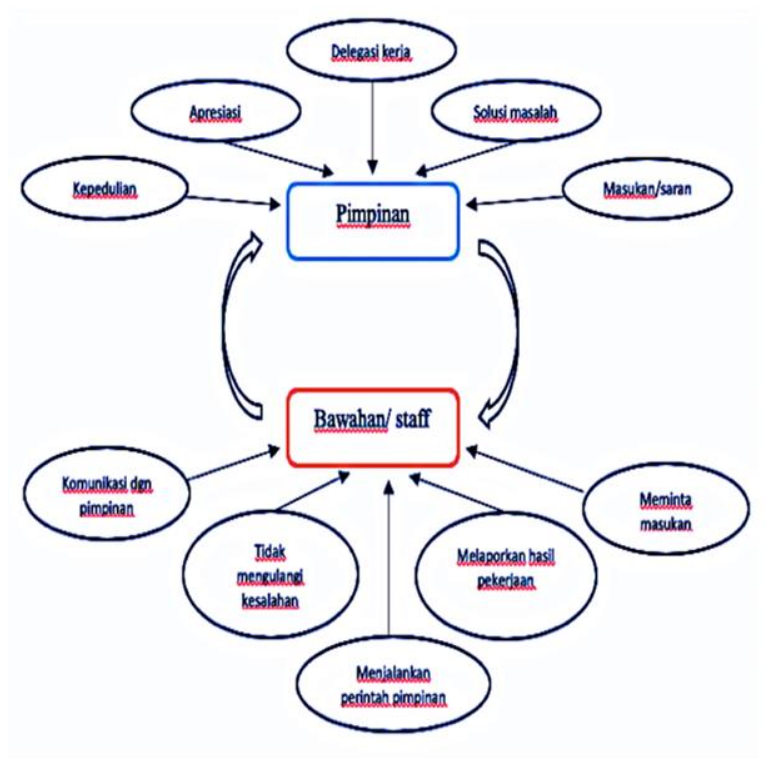

Figure 4. Trust building diagram Source: Schaap (2020)

Leaders and subordinates must have the nature or character behind the trust process. Schap (2020)argues that building trust can be aimed at various actors and audiences other than the 'public' in the general sense. Finally, in the international context, one must recognize the issues surrounding (implicit and explicit) linguistic and cultural differences around conceptualizing beliefs and building trust. For the most part, the answer to whether something can be considered a trustbuilding strategy, therefore, lies aspect itself. That means the understanding of trust-building strategies is flexible. Legood, Thomas \& Sacramento (2016)revealed that in varying trust-building processes as a leader functions seniority in terms of organizational position and across different trust dimensions was an essential contribution to the leadership and trust literature. The expression P1 also describes:

"Communication always went well between superiors and subordinates or leaders in terms of this AK-1 or yellow card service. We also always provide input to the leadership related to this service so that in the future this service is better".

\section{A process on commitment (commitment to process)}

The commitment was defined as part of the responsibility for work or individual personal statements to carry out and carry out what had been a planned goal or target. Commitment can mean a relationship of attachment both between one individual and another individual or between groups.

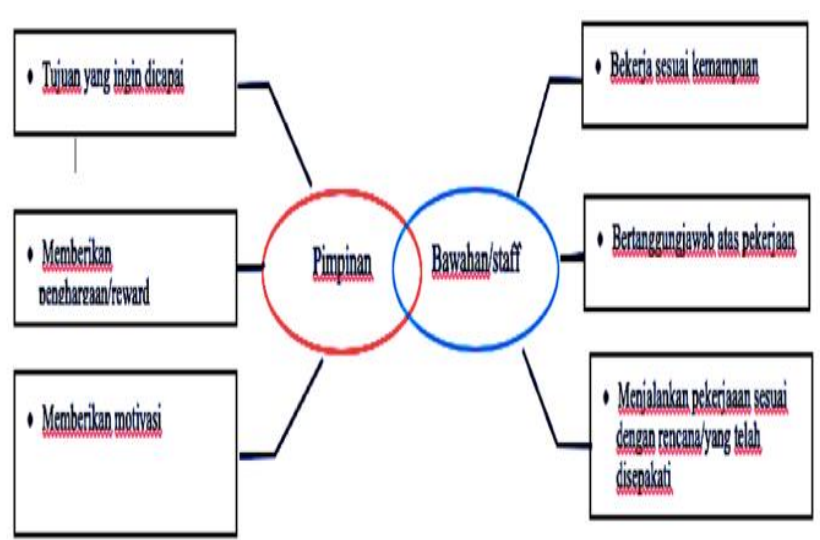

Figure 5. Diagram of the process on commitment Source: He., Hu., Swanson., Su., \& Chen (2008)

The relationship between leaders and subordinates with each task formed a bond to cooperate in achieving the planned goals. He, X., Hu, D., Swanson, SR, Su, L., \& Chen, 2018) expressed was defined normative/cognitive commitment as feeling obligated to continue. In contrast, emotional involvement was described as affective commitment, and the motivational trait was expressed as coactive commitment. De Jong, JP, Wilkin, CL, \& Rubino (2019)said the commitment from the organization had been widely used as a 
significant indicator of employee attitudes. Commitment can take three forms: (a) practical commitment (i.e., emotional attachment to organizational goals and values); (b) continuance commitments (i.e., commitments based on co-benefits and exit costs); and (c) normative commitment (i.e., feeling obligated to remain with the organization). A closed system should also be associated with more outstanding affective commitment due to higher organizational support, fairness, and equal treatment. After controlling for significant individual and country-level factors, it was shown that only continuance and normative commitment, but not an affective commitment, were associated with the type of staffing system. The results of the interview P1 said, "commitment is stated in the integrity pact, in integrity pact we have also made such a contract with the leadership. We must carry out this commitment seriously, what we have made an agreement with the leadership, we must carry out as well as possible. Therefore, the service organization in this job seeker card was able to be carried out properly".

\section{Shared understanding}

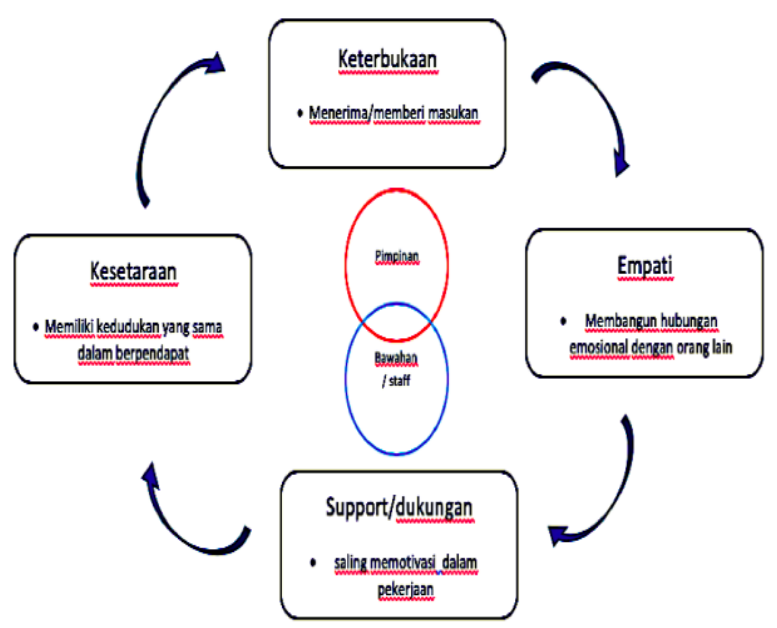

Figure 6. Sharing understanding diagram. Source: Johnson \& O'Connor (2008)

Uniting thought was a first step in establishing good cooperation, and it cannot be separated from an open attitude both in conveying information or making decisions. Meetings are a medium to harmonize ideas and produce a shared understanding that aims to make it easier to carry out a planned activity.

The elements of openness, empathy, support, and equality are the beginning of building communication. Johnson \& O'Connor, (2008)Expressing shared understanding is a crucial measure of communication effectiveness in distributed teams. Factors including social interaction influence this. FurtherChiu, C.-M., M.-H. Hsu (2006) stated that a common understanding combines several subelements, including a shared vision, goals, and ambitions. Blickensderfer, EL, Reynolds, R., Salas, E., \& Cannon-Bowers (2010) argue that shared understanding is when two or more people think synergistically (i.e., share coordinated thoughts) during specific scenarios on previous experiences appearing together. ThusSalas, E., Shuffler, ML, Thayer, AL, Bedwell, WL, \& Lazzara (2015) highlight the importance of successful task work and teamwork about effective team performance, with the two interdependent. For example, a team with high task skills but doesn't work well together is more likely to be unable to work together effectively. P3 explains that

"We were here to share one perception. In fact, we always hold coordination meetings to sit together to equate perceptions, whose name was difference, but in the end it also became a common ground".

\section{Intermediate Outcomes}

Intermediate results were able to be assumed as an indicator that the collaboration process carried out was running according to what had been agreed or planned. 


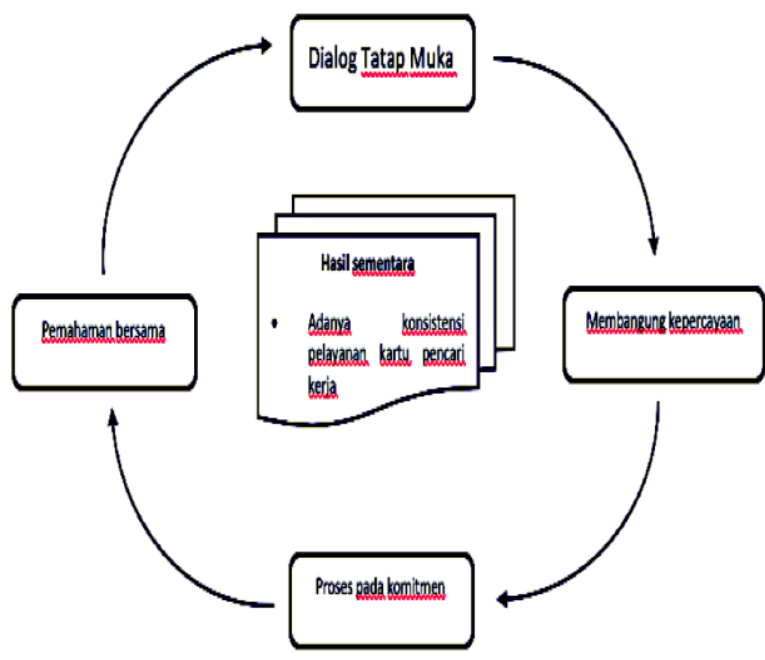

Figure 7. Diagram of provisional results Source: Vangem Siv (2003).

As part of the stages of the collaboration process, intermediate outcomes were able to be used as a benchmark for comparison of the final results to be achieved as well; from this point, stakeholders were able to assess whether the collaboration process carried out was successful or failed. Explanation from P1 that:

"We did not change the position of personnel, so we try to keep the personnel the people so that this service can continue to run even during breaks." Vangem Siv (2003)said that while these intermediate outcomes may represent tangible outcomes, they were essential to building momentum that can lead to successful collaborations. These small wins were feedback into the collaborative process, driving a virtuous cycle of trust and commitment building. The following was an overview of the intermediate outcomes.

\section{Supporting and Inhibiting Factors in Services.}

Supporting factors in service were one of the keys to the success of public service delivery; in this case, information technology (IT) facilities with the application and internet network were able to have a direct effect such as the level of satisfaction and speed of service received by the community as the target of the services provided. Given. P1 explains that:

"There was an application for employment and industrial information systems. Information on job seeker card services has also been launched, this is very helpful in disseminating the services available at the Office to the public".

The service's inhibiting factor was from the aspect of human resources owned both in terms of quantity and quality.

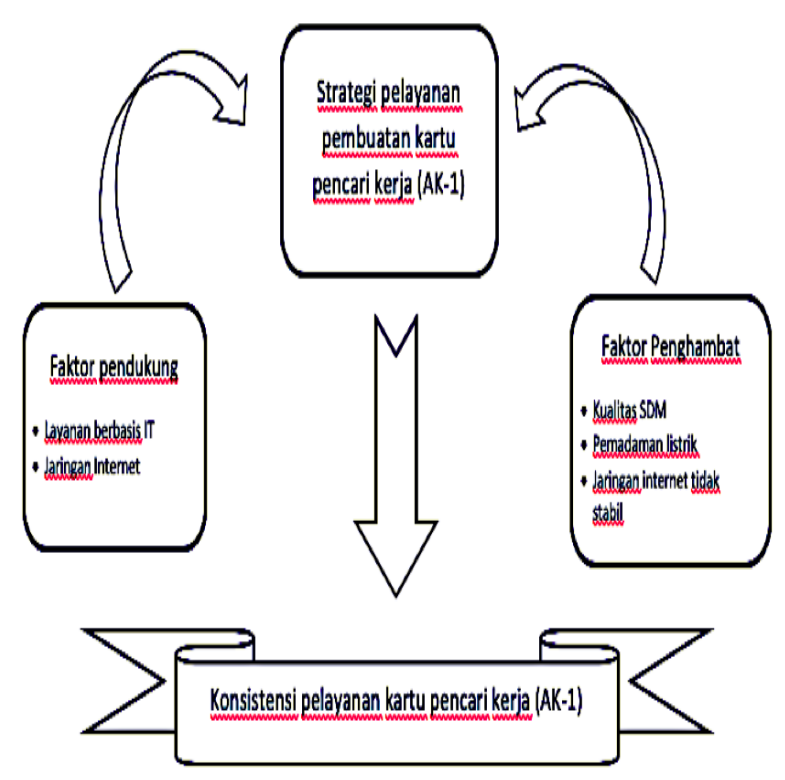

Figure 8. Diagram of the factors supporting and inhibiting services

Source: Muhammad Elwan (2019)

Based on Rosa (2019) stated that the inhibiting and supporting factors in improving service quality, the supporting factor, namely information technology communication, and the inhibiting factor was the problem of the internet network which sometimes had a slow connection, electricity often went out, so work was hampered, and human resources, since there were still some employees who could not get maximum performance because not all employees can use or operate technology such as computers and devices. Supporting factors and inhibiting factors are variables that contribute indirectly to the service strategy applied. In line with the description above, Muhammad Elwan 
(2019)stated that the factors that hinder the bureaucracy from improving the quality of public services, namely human resources who carry out service tasks, are not optimal; it happens because of limited human resources in utilizing existing resource facilities. The opinion of $\mathrm{P} 2$ that:

"Since the Covid-19 outbreak yesterday, starting in the third month, the marching activity was no longer being held, we also had limited meetings because many people are needed in a closed room, but we still hold meetings for activities that are urgent and are only attended by structural officials."

\section{CONCLUSION}

The collaboration process between structural officials and staff at the Department of Manpower and Industry of Tarakan City had been going well. However, things still need to be improved, such as the delivery of existing problems in the service, which were only discussed at meetings or field meetings. The decision-making process must be waiting for the meeting to take place. Arrangement of additional hours for services helped assist the duties of officers/operators to realize consistent service to the community, especially job seekers (non-stop service). Apart from setting working hours for services, another aspect that has received less attention was the absence of rewards to officers/operators for their work performance. The agreement on the performance of service officers and staff inservice was undoubtedly essential in controlling the performance of AK-1 staff and service officers. Still, did not implement; there was no service officer performance agreement and no description of the division of tasks signed with the leadership.

Regarding the conditions before and after the Covid-19 pandemic, it also affected the service system. Still, it did not eliminate the essence of the collaboration process built but instead switched to digital media.
Likewise, with the job seeker card service, the strategy implemented was to provide PPE equipment such as masks for officers/operators. were carried out services according to health procedures to prevent COVID-19.

The factors that supported the service of making job seeker cards at the Department of Manpower and Industry of Tarakan City were the application of the employment system. The attitude of openness in receiving input and suggestions positively impacted building trust between leaders and subordinates, especially for improving services to the community. Motivating subordinates, in this case, both to staff and officers/operators, also contributed. In carrying out their duties, subordinates can be more optimal in providing services to job seekers.

\section{REFERENCES}

Agustina, D. (2017). Kolaborasi Antara Aparatur Birokrasi Pemerintah Daerah Istimewa Yogyakarta Dan Forum Pengurangan Risiko Bencana (FPRB) DIY dalam Penyelenggaraan Penanggulangan Bencana di Daerah Istimewa Yogyakarta. Jurnal Ilmiah Ilmu Administrasi, 9(1), 87-103.

Ansell, C., \& Gash, A. (2007). Collaborative Governance In Theory And Practice. Journal of Public Administration Research and Theory, 18(4), 543-571.

Blickensderfer, E. L., Reynolds, R., Salas, E., \& Cannon-Bowers, J. A. (2010). Shared Expectations and Implicit Coordination in Tennis Doubles Teams. Journal of Applied Sport Psychology, 22, 486-499.

Chiu, C.-M., M.-H. Hsu, and E. T. G. W. (2006). Understanding Knowledge Sharing In Virtual Communities: An Integration of Social Capital and Social Cognitive Theories. Decision Support Systems, 42(3), 1872-1888.

De Jong, J. P., Wilkin, C. L., \& Rubino, C. (2019). The Association between Perceived Personal Power, Team Commitment and Intrinsic Motivation For Permanent and Temporary Workers. Economic and Industrial Democracy, 40(2), 257-279.

Fairuza, M. (2017). Kolaborasi Antar Stakeholder dalam Pembangunan Inklusif pada Sektor Pariwisata (Studi Kasus Wisata Pulau Merah di Kabupaten Banyuwangi). Jurnal Kebijakan Dan Manajemen Publik, 5(3), 1-15. 
He, X., Hu, D., Swanson, S. R., Su, L., \& Chen, X. (2018). Destination Perceptions, Relationship Quality, and Tourist Environmentally Responsible Behavior. Tourism Management Perspectives, 28, 93-104.

Irawan, D. (2017). Collaborative Governance (Studi Deskriptif Proses Pemerintahan Kolaboratif Dalam Pengendalian Pencemaran Udara Di Kota Surabaya). Jurnal Kebijakan Dan Manajemen Publik, 5(3), 1-12.

Jensen, U. T., Moynihan, D. P., \& Salomonsen, H. H. (2018). Communicating The Vision: How Face-To-Face Dialogue Facilitates Transformational Leadership. Public Administration Review, 78(3), 350-361.

Johnson, T. E., \& O'Connor, D. L. (2008). Measuring Team Shared Understanding Using The Analysis-Constructed Shared Mental Model Methodology. Performance Improvement Quarterly, 21(3), 113-134. https://doi.org/10.1002/piq.20034

Legood, A., Thomas, G., \& Sacramento, C. (2016). Leader Trustworthy Behavior And Organizational Trust: The Role of The Immediate Manager for Cultivating Trust. Journal of Applied Social Psychology, 46(12), 673-686.

Liu, X., \& Zheng, L. (2018). Cross-Departmental Collaboration In One-Stop Service Center For Smart Governance In China: Factors, Strategies, And Effectiveness. Government Information Quarterly, 35(4), S54-S60.

Miles, M. B., Huberman, A. M., \& Saldana, J. (2015). Qualitative Data Analysis, A Methods Sourcebook. Sage Publication.
Moenir, H. (2014). Manajemen Pelayanan Umum Di Indonesia. Jakarta: Bumi Aksara.

Muhammad Elwan, L. O. (2019). Problem Birokrasi Dalam Meningkatkan Pelayanan Publik Pada Sekretariat Daerah Kabupaten Muna. Journal Publicuho, 2(2), 31.

Plummer, R., and F. (2004). Co-management of Natural Resources: A Proposed Framework. Environmental Management.

Ramadass, S. D., Sambasivan, M., \& Xavier, J. A (2018). Collaboration Outcomes In A Public Sector: Impact Of Governance, Leadership, Interdependence And Relational Capital. Journal of Management and Governance, 22(3), 749-771.

Ratminto, \& Septiwinarsi, A. (2005). Manajemen pelayanan. Yogyakarta, Pustaka Pelajar

Rosa, A. T. R. (2019). Effectiveness of The Role of Information Systems and Policy Systems in Educational Management To Improve The Quality of Public Service in Cileunyi District, Bandung Regency. Jurnal Ilmu Pemerintahan Widya Praja, 45(1), 99-108.

Salas, E., Shuffler, M. L., Thayer, A. L., Bedwell, W. L., \& Lazzara, E. H. (2015). Understanding and Improving Teamwork in Organizations: A Scientifically Based Practical Guide. Human Resource Management, 54(4), 599-622.

Schaap, D. (2020). Police Trust-Building Strategies. A Socio-Institutional, Comparative Approach. Policing and Society, 1-17.

Vangem Siv, and C. H. (2003). Enacting Leadership for Collaborative Advantage: Dilemmas of Ideology and Pragmatism in The Activities of Partnership Managers. British Journal of Management, 14(1), 61-76. 